\title{
THE RENAL EFFECTS OF THE GOUTWEED (AEGOPODIUM PODAGRARIA L.) TINCTURE AND METFORMIN IN DEXAMETHASONE-TREATED RATS
}

\author{
O.V.Tovchiga, S.Yu.Shtrygol', A.V.Taran, T.K.Yudkevich
}

National University of Pharmacy

Key words: Aegopodium podagraria L.; dexamethasone; metformin; rats; combined drugs; kidney

\begin{abstract}
The tincture obtained from the goutweed (Aegopodium podagraria L.) aerial part is characterized by favourable metabolic and organoprotective effects and can partially increase the efficacy of metformin in the animals receiving high doses of dexamethasone. The aim of this study was to assess the effect of the goutweed tincture combined with metformin on the excretory renal function and the state of mineral metabolism in dexamethasone-treated rats. The animals were divided into 5 groups as follows: intact control, dexamethasone (untreated), dexamethasone + metformin, $50 \mathrm{mg} / \mathrm{kg}$ intragastrically; dexamethasone + goutweed tincture, $1 \mathrm{ml} / \mathrm{kg}$ intragastrically; dexamethasone + metformin, $50 \mathrm{mg} / \mathrm{kg}$ intragastrically + goutweed tincture, $1 \mathrm{ml} / \mathrm{kg}$ intragastrically. Dexamethasone was administered in the dose of $5 \mathrm{mg} / \mathrm{kg}$ subcutaneously for 5 days. On day 5 the status of the excretory renal function (ERF) was assessed in the water-loading test. No evidence of the abrupt changes in the functional state of the kidney was observed under the effect of dexamethasone. Combination of the goutweed tincture with metformin did not cause an unfavourable effect on the kidney function; it was evident from the stability of partial kidney function markers, including the indices of sodium transport, as well as the plasma electrolyte content. The advantages of the combination studied (compared to the monotherapy with metformin) are reduction of proteinuria and enzymuria, as well as normalization of the blood potassium content increased against the background of dexamethasone. The results substantiate the expedience of combining the goutweed tincture with metformin and the further studies of such combination.
\end{abstract}

$\mathrm{T}$ he combined use of conventional medicines with herbal drugs and phytochemical constituents necessitate verification of the expediency of such combinations. These aspects are of special significance in case of metabolic syndrome and type 2 diabetes because of the need in lifelong treatment together with high prevalence of these diseases. Potential herb-drug pharmacokinetic and pharmacodynamic interactions are highly possible in such patients who are getting more interested in traditional herbal medicines. From the other point of view, herbal drugs may enhance the efficacy of the conventional antihyperglycemic medicines and favourably broaden their pharmacodynamics [16].

The object of our study is goutweed (Aegopodium podagraria L., GW) that has been used in traditional medicine for a long time and is under extensive research now. Hydroxycinnamic acids, flavonoids, protein-polysaccharide complex components, micro- and macroelements were identified in its raw material $[6,14]$. A dry extract and the tincture obtained from the GW aerial part are standardized for the hydroxycinnamic acids content and are characterized by the low toxicity level confirmed experimentally $[6,8]$. These drugs exert the antihyperglycemic, normouricemic, nephro- and hepatoprotective effects $[6,8,17]$. Only the GW tincture appeared to be especially effective in carbohydrate metabolism disorders, and recently the expediency of its combining with metformin as the widely prescribed first line agent of peroral normoglycemic drugs was substantiated $[18,19]$. The tincture partially increases the efficacy of metformin in dexamethasone-treated rats (the permissive effect in regard to glucose and lipid metabolism normalization, reduction in the plasma ALT activity and increase in the urea clearance, as well as normalization of the plasma ALP activity) $[18,19]$. It is ge- nerally accepted that the kidney is among the target organs in diabetes and dyslipidemia, while polymodal nephrotropic effects are inherent to the GW tincture $[6,8$, 17]; therefore, it is expedient to complete the aforesaid data with the results concerning the kidney function and mineral metabolism.

The aim of this study was to assess the effect of the goutweed tincture combined with metformin on the excretory renal function and the state of mineral metabolism in dexamethasone-treated rats.

\section{Materials and Methods}

Outbred albino rats from the Central Research Laboratory of the National University of Pharmacy were used. Male rats weighing 180-240 g were kept under controlled standard conditions, on a natural light-dark cycle [4]. All the protocols were approved by the Bioethics Commission of the National University of Pharmacy and were in accordance with "Directive 2010/63/EU of the European Parliament and of the Council of 22 September 2010 on the pro- 
tection of animals used for scientific purposes."

The animals were divided into 5 groups as follows: intact control, dexamethasone (untreated), dexamethasone + metformin, $50 \mathrm{mg} / \mathrm{kg}$ intragastrically; dexamethasone + GW tincture, $1 \mathrm{ml} / \mathrm{kg}$ intragastrically; dexamethasone + metformin, $50 \mathrm{mg} / \mathrm{kg}$ intragastrically + GW tincture, $1 \mathrm{ml} / \mathrm{kg}$ intragastrically ( $n=6-7$ in each group). Dexamethasone (solution for injection, $4 \mathrm{mg} / \mathrm{ml}$, KRKA, d. d., Slovenia) was administered in the dose of $5 \mathrm{mg} / \mathrm{kg}$ subcutaneously for 5 days as characterized previously $[18,19]$. Metformin was used in the dose of $50 \mathrm{mg} / \mathrm{kg}$ intragastrically since it was expedient to use low doses while studying the possibility of synergism (still this dose was found to be effective on the model of diabetes [20]). The dose of $1 \mathrm{ml} / \mathrm{kg}$ intragastrically in the GW tincture was chosen since being safe in the intact animals [17] it demonstrated efficacy in animals with carbohydrate metabolism disorders as described in $[18,19]$. The interval between the administration of the GW tincture and metformin equalled 40 min to minimize interaction at the level of absorption. On day 5 in 40 min after the drugs administration (the rats fasted for 12 hours before it) the status of the excretory renal function (ERF) was determined. After introduction of water loading at a rate of 3\% of the body weight the urine was collected for two hours. The animals were previously adapted to the conditions of the experiment [3]. After this, heparinized blood samples were drawn by exsanguination from barbiturate-anesthetized animals and the plasma was separated immediately by centrifugation.

The sodium and potassium content in the urine and the blood plasma was measured using the flame photometry method, creatinine - by Jaffe reaction. The protein concentration in the urine was assayed by the reaction with sul- phosalicylic acid, the alkaline phosphatase (ALP) activity - by measurement of the amount of phenol liberated from the hydrolysed substrate. The content of calcium and inorganic phosphates in the plasma was determined using the reactions with arsenazo III ligand and with molybdic acid, respectively. Commercially-available kits from Filisit-Diagnostika (Ukraine) were used. By the generally accepted formula, creatinine, protein, sodium and potassium excretion were calculated, as well as $\mathrm{Na}^{+} / \mathrm{K}^{+}$ratio in the urine and plasma. The creatinine and sodium concentration in the plasma and urine were also used for estimation of the glomerular filtration rate (GFR), the relative water reabsorption $\left(\mathrm{R}_{\mathrm{H} 20}\right)$, the absolute and relative sodium reabsorption, its proximal and distal transport ( $\mathrm{RpNa}^{+}$and $\mathrm{RdNa}^{+}$) [7].

Medians, 25\% and 75\% percentiles (upper and lower quartiles), were calculated, as well as the traditionally used arithmetic means and their standard errors $(\mathrm{M} \pm \mathrm{m})$. Taking into account a problematical character of multiple comparisons in pharmacology and toxicology the comparison of the central tendencies of independent samples was performed using Mann-Whitney U-criterion.

\section{Results and Discussion}

Dexamethasone-induced model is commonly used for the studies of drugs affecting the pathogenetic mechanisms of type 2 diabetes and the metabolic syndrome [4]. A significant increase in basal glycemia and the liver glycogen level, as well as reduction of insulin sensitivity and tolerance to the glucose load were observed in our studies under the effect of dexamethasone in the dose of $5 \mathrm{mg} / \mathrm{kg}$ as reported previously [18]. There were negative changes in lipid metabolism and catabolic changes with the body weight decrease and increase in the plasma urea and its renal excretion. The AST and especially ALT acti- vity in the blood plasma was elevated, and it was associated with the metabolic changes (possibly gluconeogenesis intensification) rather than with a marked cytolysis (indirectly confirmed with the absence of increase of the $\gamma$-glutamyltransferase activity as a sensitive marker of the hepatocyte injury) $[18,19]$.

According to the results obtained in the current study (Tab. 1, 2) there were no changes in parameters undergoing a strict homeostatic regulation, such as plasma sodium and calcium. The creatinine content remained practically unchanged (the slight tendency to the increase was seen in all groups receiving dexamethasone), as well as the GFR rate, together with the unchanged plasma sodium providing the stability of the filtered load of $\mathrm{Na}^{+}$. All these data indicate the absence of the severe nephrotoxic effect that is expected taking into account dexamethasone pharmacological properties. Besides, this drug is characterized by the minimal mineralocorticoid activity [9]. As seen from Tab. 1, 2, the plasma and urine $\mathrm{Na}^{+} / \mathrm{K}^{+}$ratios, which are usually considered to be reliable markers of the mineralocorticoid control of the distal tubules, do not show any significant differences between the groups. In rats receiving dexamethasone the sodium and potassium excretions were equally increased (the natriuresis increase in the untreated group was not found to be statistically significant because of high inter-individual variability of this value). High inter-individual variability was also inherent to $\mathrm{RpNa}^{+}$and $\mathrm{RdNa}^{+}$, both of these values, especially $\mathrm{RpNa}^{+}$, showed a clear tendency to reduction and a statistically significant decrease in relative sodium reabsorption was observed (Tab. 2). In the animals receiving metformin relative sodium reabsorption approximated to the value of the intact control, and the excretion of this cation slightly decreased. When metformin was used in com- 
The effect of the goutweed tincture and metformin on the biochemical values of plasma in rats receiving dexamethasone; Mean \pm S.E.M; $Q_{50}\left(Q_{25}-Q_{75}\right)$, $n=5-7$ in each group

\begin{tabular}{|c|c|c|c|c|c|}
\hline Indices & Intact control & Dexamethasone & $\begin{array}{l}\text { Dexamethasone } \\
+ \text { metformin, } \\
50 \mathrm{mg} / \mathrm{kg}\end{array}$ & $\begin{array}{c}\text { Dexamethasone } \\
+\mathrm{GW} \text { tincture, } \\
1 \mathrm{ml} / \mathrm{kg}\end{array}$ & $\begin{array}{l}\text { Dexamethasone } \\
+ \text { metformin, } \\
50 \mathrm{mg} / \mathrm{kg}+\mathrm{GW} \\
\text { tincture, } 1 \mathrm{ml} / \mathrm{kg}\end{array}$ \\
\hline $\begin{array}{l}\text { Plasma creatinine, } \\
\mu \mathrm{M} / \mathrm{l}\end{array}$ & $\begin{array}{c}64.7 \pm 3.20 \\
\mathbf{6 5 . 8} \\
(58.1-71.3)\end{array}$ & $\begin{array}{c}75.6 \pm 4.25 \\
\mathbf{7 8 . 8} \\
(70.5-79.3) \\
\end{array}$ & $\begin{array}{c}71.4 \pm 3.40 \\
70.5 \\
(70.5-70.5) \\
\end{array}$ & $\begin{array}{c}67.9 \pm 2.78 \\
70.5 \\
(64.3-72.1) \\
\end{array}$ & $\begin{array}{c}73.0 \pm 4.38 \\
74.6 \\
(67.0-78.8)\end{array}$ \\
\hline $\begin{array}{l}\text { Plasma sodium, } \\
\mathrm{mmol} / \mathrm{l}\end{array}$ & $\begin{array}{c}154 \pm 5.84 \\
146 \\
(141-169)\end{array}$ & $\begin{array}{c}150 \pm 5.88 \\
\mathbf{1 5 0} \\
(144-158)\end{array}$ & $\begin{array}{c}147 \pm 6.81 \\
148 \\
(140-152)\end{array}$ & $\begin{array}{c}148 \pm 6.79 \\
147 \\
(140-152)\end{array}$ & $\begin{array}{c}145 \pm 6.79 \\
148 \\
(131-160)\end{array}$ \\
\hline $\begin{array}{l}\text { Plasma potassium, } \\
\mathrm{mmol} / \mathrm{l}\end{array}$ & $\begin{array}{c}4.17 \pm 0.15 \\
4.23 \\
(3.95-4.37) \\
\end{array}$ & $\begin{array}{c}4.88 \pm 0.38^{*} \\
4.75 \\
(4.29-5.24) \\
\end{array}$ & $\begin{array}{c}4.96 \pm 0.20^{* \wedge} \\
\mathbf{5 . 0 4} \\
(4.60-5.12) \\
\end{array}$ & $\begin{array}{c}4.67 \pm 0.26 \\
4.39 \\
(4.30-4.99) \\
\end{array}$ & $\begin{array}{c}4.40 \pm 0.18 \\
4.30 \\
(4.22-4.73) \\
\end{array}$ \\
\hline $\begin{array}{l}\text { Plasma } \mathrm{Na}^{+} / \mathrm{K}^{+} \\
\text {ratio }\end{array}$ & $\begin{array}{c}36.0 \pm 2.44 \\
36.3 \\
(31.7-39.2)\end{array}$ & $\begin{array}{c}31.5 \pm 2.30 \\
\mathbf{3 2 . 1} \\
(21.8-33.9)\end{array}$ & $\begin{array}{c}30.9 \pm 2.35 \\
\mathbf{2 9 . 4} \\
(27.1-34.7)\end{array}$ & $\begin{array}{c}32.5 \pm 2.16 \\
32.0 \\
(28.5-34.5)\end{array}$ & $\begin{array}{c}33.1 \pm 1.39 \\
\mathbf{3 2 . 5} \\
(30.4-35.7)\end{array}$ \\
\hline $\begin{array}{l}\text { Plasma calcium, } \\
\mathrm{mmol} / \mathrm{l}\end{array}$ & $\begin{array}{c}2.11 \pm 0.09 \\
\mathbf{2 . 1 2} \\
(1.97-2.24)\end{array}$ & $\begin{array}{c}2.11 \pm 0.14 \\
\mathbf{2 . 0 6} \\
(1.95-2.29)\end{array}$ & $\begin{array}{c}1.97 \pm 0.13 \\
\mathbf{2 . 0 3} \\
(1.70-2.22)\end{array}$ & $\begin{array}{c}2.11 \pm 0.09 \\
\mathbf{2 . 1 0} \\
(2.08-2.19)\end{array}$ & $\begin{array}{c}1.86 \pm 0.15 \\
1.90 \\
(1.73-2.03)\end{array}$ \\
\hline $\begin{array}{l}\text { Plasma inorganic } \\
\text { phosphate, } \mathrm{mmol} / \mathrm{l}\end{array}$ & $\begin{array}{c}2.17 \pm 0.43 \\
\mathbf{2 . 2 3} \\
(1.23-3.09)\end{array}$ & $\begin{array}{c}2.51 \pm 0.14 \\
\mathbf{2 . 4 8} \\
(2.23-2.79)\end{array}$ & $\begin{array}{c}2.18 \pm 0.20^{\wedge} \\
\mathbf{2 . 1 3} \\
(1.95-2.50)\end{array}$ & $\begin{array}{c}2.73 \pm 0.24 \\
\mathbf{2 . 4 3} \\
(2.38-3.19)\end{array}$ & $\begin{array}{c}3.03 \pm 0.16^{\#} \\
3.14 \\
(2.99-3.18)\end{array}$ \\
\hline
\end{tabular}

Note. ${ }^{*}-p<0.05$ compared to the intact control; $\#-p<0.05$ compared to the untreated group; $\wedge-p<0.05$ compared to the group receiving metformin and GW tincture. GW - goutweed. Medians are given in bold.

bination with the GW tincture, these changes were not observed, and the indices of sodium transport were close to that of the untreated group receiving dexamethasone. The same situation was registered in rats receiving GW reduction per se. Besides, in both groups treated with the tincture there was a decline of $\mathrm{R}_{\mathrm{H}_{2} 0}$, and it reached its statistical significance in the group receiving the combination studied. Diuresis was increased to some extent in these rats.

An increase in the plasma potassium level was seen in dexamethasone-treated rats. The significantly increased potassium excretion in the untreated group indicates the counteraction of the renal mechanisms to hyperkalemia development, still not providing the complete normalization of this value. The changes in potassium exchange in this group can be attributed to redistribution of the cation between tissue depots and the blood plasma. It can be noted that these processes are closely interrelated with insulin effects and its ability to increase the cellular potassium uptake is generally known. Potassium exchange is considered as an important link between carbohydrate metabolism and renin-angiotensin-aldosterone system (RAAS) with the numerous feedbacks [12]. As described previously [18], insulin resistance was clearly seen in dexamethasone-treated rats, but further research is needed to verify an assumption about its involvement into potassium redistribution. However, neither insulin resistance [18], nor the plasma potassium level (Tab. 1) improved under the effect of metformin (presumably because of the respectively low dose used). It has been shown that the state of RAAS is not indifferent for metformin efficacy in diabetic animals [15], but in that work a substantial RAAS activation was achieved, and it was not seen in our studies. The GW tincture, in contrast to metformin, was able to normalize the plasma potassium: this value in both groups treated with the tincture did not show any significant differences with the intact group data, and statistically significant differences were registered between the group receiving metformin per se and the group receiving the combination studied. In the latter the potassium excretion increased insignificantly, and, as stated above, there were no distinct signs of aldosterone involvement into these changes. Therefore, kalemia maintenance is with high probability linked to the extrarenal mechanisms of the GW tincture action and can be associated with overcoming insulin resistance [18], as well as with the other processes at the level of membrane transport (phenolic compounds present in GW can mediate such effects as discussed in $[6,18])$. In the context of the parameters studied it is not without interest that the inorganic phosphates content in the plasma increased in the group re- 
The effect of the goutweed tincture and metformin on the kidney function in rats receiving dexamethasone; Mean \pm S.E.M; $Q_{50}\left(Q_{25}-Q_{75}\right), n=5-7$ in each group

\begin{tabular}{|c|c|c|c|c|c|}
\hline Indices & Intact control & Dexamethasone & $\begin{array}{l}\text { Dexamethasone } \\
+ \text { metformin, } \\
50 \mathrm{mg} / \mathrm{kg}\end{array}$ & $\begin{array}{l}\text { Dexamethasone } \\
+\mathrm{GW} \text { tincture, } \\
1 \mathrm{ml} / \mathrm{kg}\end{array}$ & $\begin{array}{l}\text { Dexamethasone } \\
+ \text { metformin, } \\
50 \mathrm{mg} / \mathrm{kg}+\mathrm{GW} \\
\text { tincture, } 1 \mathrm{ml} / \mathrm{kg}\end{array}$ \\
\hline $\begin{array}{l}\text { Diuresis, } \\
\mathrm{ml} / 100 \mathrm{~g} \text { for } 2 \mathrm{~h}\end{array}$ & $\begin{array}{c}2.18 \pm 0.26 \\
\mathbf{2 . 0 7} \\
(1.62-2.76) \\
\end{array}$ & $\begin{array}{c}1.87 \pm 0.25 \\
\mathbf{2 . 1 5} \\
(1.54-2.30) \\
\end{array}$ & $\begin{array}{c}2.13 \pm 0.40 \\
\mathbf{2 . 0 9} \\
(1.56-2.87) \\
\end{array}$ & $\begin{array}{c}2.30 \pm 0.33 \\
\mathbf{2 . 0 0} \\
(1.73-2.89) \\
\end{array}$ & $\begin{array}{c}2.97 \pm 0.50 \\
3.31 \\
(2.31-3.71) \\
\end{array}$ \\
\hline $\begin{array}{l}\text { Creatinine excretion, } \\
\mu \mathrm{M} / 100 \mathrm{~g} \text { for } 2 \mathrm{~h}\end{array}$ & $\begin{array}{c}4.72 \pm 0.31 \\
5.01 \\
(4.48-5.04) \\
\end{array}$ & $\begin{array}{c}4.36 \pm 0.40 \\
\mathbf{4 . 0 3} \\
(3.62-5.21) \\
\end{array}$ & $\begin{array}{c}5.17 \pm 0.59 \\
5.44 \\
(5.07-6.15) \\
\end{array}$ & $\begin{array}{c}4.05 \pm 0.72 \\
\mathbf{3 . 7 5} \\
(2.71-4.93) \\
\end{array}$ & $\begin{array}{c}4.93 \pm 0.79 \\
\mathbf{4 . 7 9} \\
(3.55-5.69) \\
\end{array}$ \\
\hline $\mathrm{GFR}, \mathrm{ml} / \mathrm{min}$ for $100 \mathrm{~g}$ & $\begin{array}{c}0.611 \pm 0.038 \\
\mathbf{0 . 6 0 0} \\
(0.538-0.667) \\
\end{array}$ & $\begin{array}{c}0.493 \pm 0.065 \\
\mathbf{0 . 4 7 7} \\
(0.381-0.572) \\
\end{array}$ & $\begin{array}{c}0.580 \pm 0.082 \\
\mathbf{0 . 5 8 9} \\
(0.555-0.714) \\
\end{array}$ & $\begin{array}{c}0.509 \pm 0.097 \\
\mathbf{0 . 4 6 5} \\
(0.308-0.708) \\
\end{array}$ & $\begin{array}{c}0.569 \pm 0.100 \\
\mathbf{0 . 5 0 9} \\
(0.426-0.599) \\
\end{array}$ \\
\hline $\begin{array}{l}\text { Filtered load of } \mathrm{Na}^{+} \text {, } \\
\mu \mathrm{M} / \mathrm{min} \text { per100 g }\end{array}$ & $\begin{array}{c}93.4 \pm 5.81 \\
90.3 \\
(87.0-101.9) \\
\end{array}$ & $\begin{array}{c}73.7 \pm 11.0 \\
\mathbf{7 0 . 9} \\
(57.7-97.0) \\
\end{array}$ & $\begin{array}{c}80.3 \pm 12.1 \\
\mathbf{8 3 . 5} \\
(70.2-93.5) \\
\end{array}$ & $\begin{array}{c}74.8 \pm 14.2 \\
66.5 \\
(47.0-100.1) \\
\end{array}$ & $\begin{array}{c}83.6 \pm 17.2 \\
\mathbf{7 0 . 6} \\
(57.5-83.4) \\
\end{array}$ \\
\hline $\begin{array}{l}\text { ALP activity in the } \\
\text { urine, } \mu \text { cat/l }\end{array}$ & $\begin{array}{c}1.09 \pm 0.36 \\
\mathbf{1 . 1 7} \\
(0.30-1.55) \\
\end{array}$ & $\begin{array}{c}1.66 \pm 0.21 \\
\mathbf{1 . 8 3} \\
(1.33-1.90) \\
\end{array}$ & $\begin{array}{c}1.88 \pm 0.51 \\
\mathbf{1 . 5 7} \\
(0.94-2.89) \\
\end{array}$ & $\begin{array}{c}0.88 \pm 0.27^{\#} \\
\mathbf{0 . 6 6} \\
(0.53-1.37) \\
\end{array}$ & $\begin{array}{c}1.10 \pm 0.38 \\
\mathbf{0 . 7 3} \\
(0.53-1.27) \\
\end{array}$ \\
\hline $\begin{array}{l}\text { ALP activity in the } \\
\text { urine, } \mu \text { cat } / 1 \mathrm{~g} \text { of the } \\
\text { excreted protein }\end{array}$ & $\begin{array}{c}14.2 \pm 4.45 \\
\mathbf{1 3 . 2} \\
(7.71-16.7) \\
\end{array}$ & $\begin{array}{c}17.0 \pm 3.11 \\
15.1 \\
(13.2-17.7) \\
\end{array}$ & $\begin{array}{c}9.07 \pm 2.00 \\
\mathbf{7 . 8 9} \\
(6.70-11.2) \\
\end{array}$ & $\begin{array}{c}6.98 \pm 2.61^{\# \#} \\
\mathbf{4 . 2 4} \\
(3.84-10.6) \\
\end{array}$ & $\begin{array}{c}11.3 \pm 3.32^{\#} \\
9.57 \\
(8.00-10.5) \\
\end{array}$ \\
\hline $\begin{array}{l}\text { ALP activity in the } \\
\text { urine, } \mu \text { cat } / 1 \mu \mathrm{mol} \text { of } \\
\text { creatinine }\end{array}$ & $\begin{array}{c}0.216 \pm 0.070 \\
\mathbf{0 . 2 6 0} \\
(0.061-0.287) \\
\end{array}$ & $\begin{array}{c}0.383 \pm 0.040^{*} \\
\mathbf{0 . 3 5 2} \\
(0.329-0.421) \\
\end{array}$ & $\begin{array}{c}0.349 \pm 0.078 \\
\mathbf{0 . 2 6 5} \\
(0.245-0.482) \\
\end{array}$ & $\begin{array}{c}0.210 \pm 0.040 \\
\mathbf{0 . 2 3 8} \\
(0.212-0.255) \\
\end{array}$ & $\begin{array}{c}0.234 \pm 0.073 \\
\mathbf{0 . 1 5 1} \\
(0.108-0.372) \\
\end{array}$ \\
\hline $\begin{array}{l}\text { Protein excretion, } \\
\mu \mathrm{g} / 1 \mathrm{ml} \text { of the } \\
\text { glomerular filtrate }\end{array}$ & $\begin{array}{c}2.10 \pm 0.36 \\
\mathbf{2 . 0 6} \\
(1.49-2.11) \\
\end{array}$ & $\begin{array}{c}3.51 \pm 0.78 \\
\mathbf{3 . 5 3} \\
(2.02-4.49) \\
\end{array}$ & $\begin{array}{c}5.57 \pm 1.30^{* *} \\
5.46 \\
(4.06-6.97) \\
\end{array}$ & $\begin{array}{c}5.24 \pm 0.82^{* *} \\
\mathbf{4 . 8 1} \\
(3.74-6.53) \\
\end{array}$ & $\begin{array}{c}4.24 \pm 0.83^{*} \\
\mathbf{3 . 6 7} \\
(3.33-5.06) \\
\end{array}$ \\
\hline Relative $\mathrm{R}$ of $\mathrm{H}_{2} \mathrm{O}, \%$ & $\begin{array}{c}96.88 \pm 0.51 \\
\mathbf{9 7 . 5 2} \\
(95.52-98.06) \\
\end{array}$ & $\begin{array}{c}96.83 \pm 0.26 \\
96.87 \\
(96.62-97.25) \\
\end{array}$ & $\begin{array}{c}96.14 \pm 1.35 \\
\mathbf{9 7 . 2 5} \\
(95.28-97.73) \\
\end{array}$ & $\begin{array}{c}95.90 \pm 0.45 \\
95.51 \\
(95.17-96.51) \\
\end{array}$ & $\begin{array}{c}95.58 \pm 0.53^{*} \\
95.01 \\
(94.72-96.16) \\
\end{array}$ \\
\hline Absolute $\mathrm{R}$ of $\mathrm{Na}^{+}, \%$ & $\begin{array}{c}93.2 \pm 5.76 \\
\mathbf{8 9 . 8} \\
(86.9-102) \\
\end{array}$ & $\begin{array}{c}73.3 \pm 11.0 \\
\mathbf{7 0 . 5} \\
(57.4-96.6) \\
\end{array}$ & $\begin{array}{c}80.1 \pm 12.1 \\
\mathbf{8 3 . 3} \\
(70.1-93.3) \\
\end{array}$ & $\begin{array}{c}74.4 \pm 14.2 \\
66.3 \\
(46.7-99.7) \\
\end{array}$ & $\begin{array}{c}83.1 \pm 17.0 \\
\mathbf{7 0 . 2} \\
(57.2-83.1) \\
\end{array}$ \\
\hline Relative $\mathrm{R}$ of $\mathrm{Na}^{+}, \%$ & $\begin{array}{c}99.77 \pm 0.07 \\
\mathbf{9 9 . 8 1} \\
(99.70-99.90) \\
\end{array}$ & $\begin{array}{c}99.47 \pm 0.05^{*} \\
\mathbf{9 9 . 5 0} \\
(99.38-99.53) \\
\end{array}$ & $\begin{array}{c}99.67 \pm 0.14 \\
99.77 \\
(99.60-99.84) \\
\end{array}$ & $\begin{array}{c}99.47 \pm 0.11^{*} \\
99.56 \\
(99.48-99.62) \\
\end{array}$ & $\begin{array}{c}99.44 \pm 0.16 \\
99.49 \\
(99.22-99.68) \\
\end{array}$ \\
\hline $\begin{array}{l}\mathrm{Rp} \text { of } \mathrm{Na}^{+}, \mathrm{mM} / 2 \mathrm{~h} \\
\text { per100 } \mathrm{g}\end{array}$ & $\begin{array}{c}10.9 \pm 0.70 \\
\mathbf{1 0 . 6} \\
(10.1-11.8) \\
\end{array}$ & $\begin{array}{c}8.56 \pm 1.29 \\
\mathbf{8 . 1 6} \\
(6.69-11.3) \\
\end{array}$ & $\begin{array}{c}9.30 \pm 1.52 \\
\mathbf{9 . 6 6} \\
(8.14-10.8) \\
\end{array}$ & $\begin{array}{c}8.63 \pm 1.67 \\
\mathbf{7 . 6 0} \\
(5.38-11.7) \\
\end{array}$ & $\begin{array}{c}9.60 \pm 2.00 \\
\mathbf{8 . 0 2} \\
(6.68-9.48) \\
\end{array}$ \\
\hline $\begin{array}{l}\mathrm{Rd} \text { of } \mathrm{Na}^{+}, \mu \mathrm{M} / 2 \mathrm{~h} \\
\text { per100 } \mathrm{g}\end{array}$ & $\begin{array}{c}312 \pm 51.9 \\
\mathbf{2 9 3} \\
(207-427) \\
\end{array}$ & $\begin{array}{c}234 \pm 39.4 \\
\mathbf{2 5 1} \\
(199-303) \\
\end{array}$ & $\begin{array}{c}307 \pm 96.0 \\
331 \\
(172-466) \\
\end{array}$ & $\begin{array}{c}296 \pm 46.1 \\
247 \\
(229-386) \\
\end{array}$ & $\begin{array}{c}374 \pm 65.4 \\
404 \\
(286-500) \\
\end{array}$ \\
\hline $\begin{array}{l}\text { Sodium excretion, } \\
\mu \mathrm{mol} / 100 \mathrm{~g} \text { for } 2 \mathrm{~h}\end{array}$ & $\begin{array}{c}26.8 \pm 8.39 \\
\mathbf{2 3 . 8} \\
(10.4-39.8) \\
\end{array}$ & $\begin{array}{c}46.1 \pm 8.36 \\
39.6 \\
(34.9-45.9) \\
\end{array}$ & $\begin{array}{c}32.1 \pm 5.35 \\
\mathbf{3 4 . 2} \\
(24.2-40.7) \\
\end{array}$ & $\begin{array}{c}41.8 \pm 4.90 \\
\mathbf{4 3 . 6} \\
(34.7-50.4) \\
\end{array}$ & $\begin{array}{c}58.9 \pm 23.6 \\
39.8 \\
(24.5-74.8) \\
\end{array}$ \\
\hline $\begin{array}{l}\text { Potassium excretion, } \\
\mu \mathrm{mol} / 100 \mathrm{~g} \text { for } 2 \mathrm{~h}\end{array}$ & $\begin{array}{c}24.4 \pm 3.58 \\
\mathbf{2 4 . 9} \\
(17.1-30.2) \\
\end{array}$ & $\begin{array}{c}42.5 \pm 5.53^{*} \\
45.7 \\
(34.1-52.3) \\
\end{array}$ & $\begin{array}{c}25.5 \pm 6.90 \\
\mathbf{2 0 . 5} \\
(12.5-32.1) \\
\end{array}$ & $\begin{array}{c}38.7 \pm 10.7 \\
\mathbf{2 4 . 4} \\
(22.4-58.5) \\
\end{array}$ & $\begin{array}{c}40.9 \pm 12.7 \\
\mathbf{2 9 . 5} \\
(18.3-54.3) \\
\end{array}$ \\
\hline Urine $\mathrm{Na}^{+} / \mathrm{K}^{+}$ratio & $\begin{array}{c}1.32 \pm 0.56 \\
\mathbf{0 . 9 5 5} \\
(0.38-1.43) \\
\end{array}$ & $\begin{array}{c}1.09 \pm 0.11 \\
\mathbf{1 . 0 2 3} \\
(0.88-1.25) \\
\end{array}$ & $\begin{array}{c}1.68 \pm 0.53 \\
\mathbf{1 . 1 5 2} \\
(0.89-1.92) \\
\end{array}$ & $\begin{array}{c}1.34 \pm 0.21 \\
\mathbf{1 . 4 4 2} \\
(0.95-1.62) \\
\end{array}$ & $\begin{array}{c}1.25 \pm 0.20 \\
\mathbf{1 . 3 2 3} \\
(1.22-1.52) \\
\end{array}$ \\
\hline
\end{tabular}

Note. ${ }^{*}-p<0.05$ compared to the intact control; ${ }^{* *}-p<0.02$ compared to the intact control; ${ }^{* * *}-p<0.01$ compared to the intact control; \# - p<0.05 compared to the untreated group; \#\# - p<0.02 compared to the untreated group. GW - goutweed, $\mathrm{R}$ - reabsorption, $\mathrm{Rp}$ - proximal transport, $\mathrm{Rd}$ - distal transport. Medians are given in bold. 


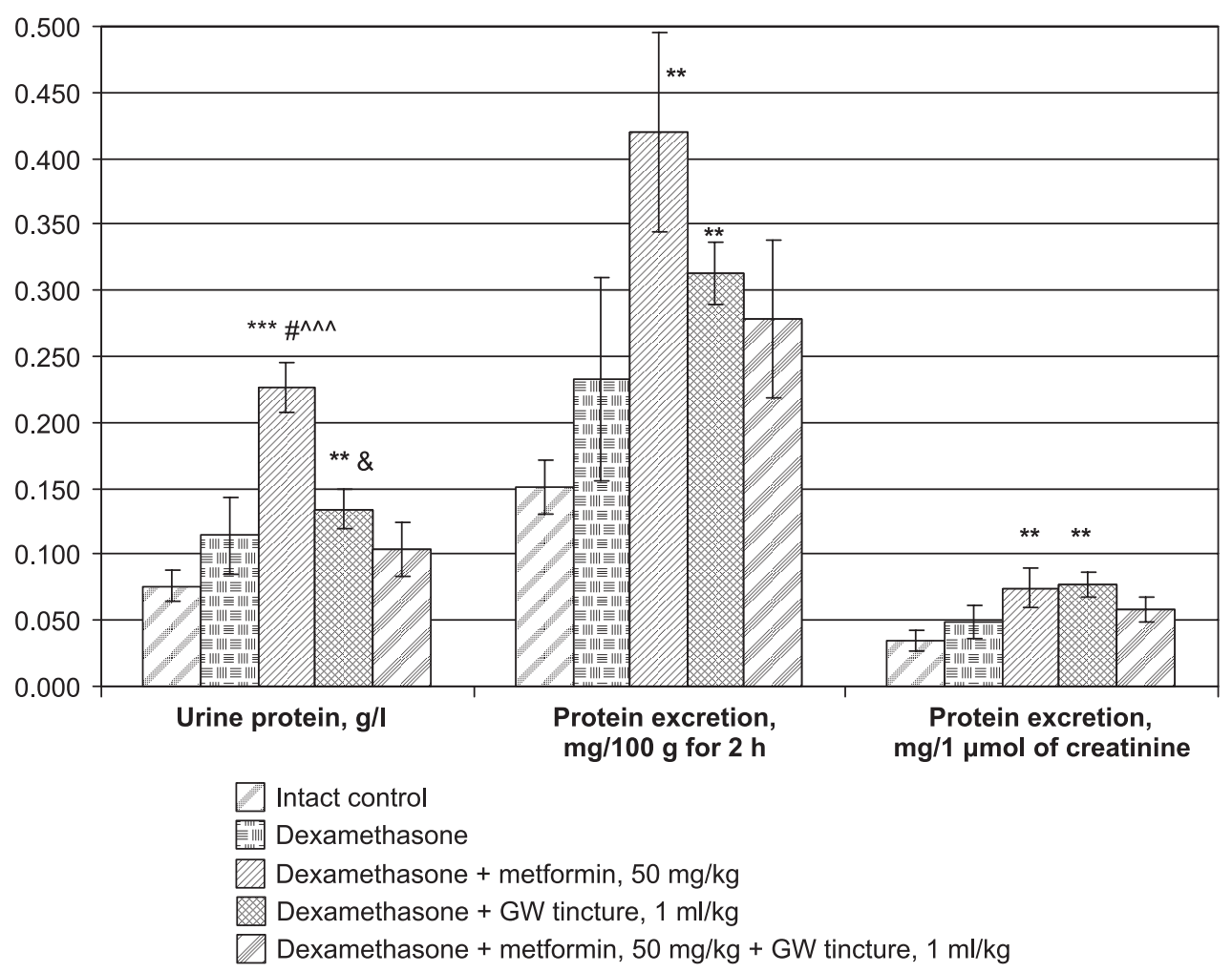

Fig. The effect of the goutweed tincture and metformin on proteinuria in rats receiving dexamethasone; Mean \pm S.E.M; $n=5-7$ in each group

Note. ${ }^{* *}-p<0.02$ compared to the intact control; ${ }^{* * *}-p<0.01$ compared to the intact control;

$\#-p<0.05$ compared to the untreated group; $\wedge \wedge \wedge-p<0.01$ compared to the group receiving metformin and GW tincture; \& $-p<0.05$ compared to the group receiving metformin. GW - goutweed

ceiving the combined treatment ( $p<0.05$ compared to the values of the untreated and to metformin-treated group), while insulin is known to stimulate renal reabsorption of phosphates [10], and renal handling is the main site of regulation of their plasma content.

The results also indicated an unexpected phenomenon, namely the tendency to the increase in proteinuria and protein excretion in rats receiving dexamethasone and a significant increase in the urine protein and its excretion (absolute, as well as standardized for creatinine excretion or the filtration rate) in animals treated with metformin (Tab. 2, Fig.). There is definitely no clinical evidence of metformin nephrotoxicity. However, targeted nephroprotective effects (exceeding the indirect benefits from metabolism and blood pressure normalization) are not inherent to this drug. In type 2 diabetic patients with incipient nephropathy no favourable changes in renal hemodynamics were seen under the effect of metformin despite the decreased urine albumin excretion rate [11], and even a slow increase in the albumin/creatinine ratio was observed in patients with type 2 diabetes treated with this drug for 5 years [13]. Thus, it seems promising to complete metformin pharmacodynamics with nephroprotective properties, and such situation occurred when it was combined with the GW tincture (which ability to counteract proteinuria was previously proven [6]). The protein content in the urine was significantly lower in rats receiving the combination compared to the animals treated with metformin per se (Tab. 2, Fig.). The decrease in all calculated values of protein excretion was not so evident, possibly, because of the increased diuresis.

The ALP activity was determined in the urine since this membrane associated enzyme indicates the structural and functional integrity of nephrons and is used in the modern experimental eva- luation of nephroprotectors [1]. There was a certain increase in this value under the influence of dexamethasone (Tab. 2), while the GW tincture per se and in combination with metformin decreased it. The difference with the untreated group was statistically significant when the values were standardized for the protein content, indicating that the effect was not completely mediated by proteinuria counteraction, which could be considered as an additional benefit.

\section{CONCLUSIONS}

1. The results of the study, together with the data obtained previously in dexamethasone-treated rats, substantiate the expedience of combining metformin with the goutweed tincture. This combination (metformin in the dose of $50 \mathrm{mg} / \mathrm{kg}$ intragastrically and the tincture in the dose of $1 \mathrm{ml} / \mathrm{kg}$ intragastrically), in contrast to the monotherapy with metformin (50 mg/kg intragastrically), demonstrates such benefits as re- 
duction of proteinuria and enzymuria (as the markers of the kidney injury), as well as normalization of potassium exchange.

2. The goutweed tincture combined with metformin does not show an unfavourable effect on the kidney function; it is evident from the stability of partial kidney function markers, including the indices of sodium transport determined in the water-loading test as well as the plasma electrolyte content.

3. It is expedient to conduct the in-depth study of interaction of the goutweed tincture with metformin.

\section{REFERENCES}

1. Азарова О.В. Экспериментальная фармакотерапия почечной патологии полифенольными комплексами клеточных культур растений: Автореф. дис. ... докт. биол. наук. - Томск, 2013. - 47 с.

2. Айзман Р.И. // Физиология и патология почек и водно-солевого обмена: матер. междунар. науч. конф., посв. 100-летию проф. Н.Н.Прониной (18-21 декабря 2012 г.). - Владикавказ, 2012. - С. 10-18.

3. Берхин Е.Б., Иванов Ю.И. Методы экспериментального исследования почек и водно-солевого обмена. - Барнаул: Алтайское книжн. изд-во, 1972. - 199 с.

4. Доклінічні дослідження лікарських засобів : метод. рек. / ред. чл.-кор. НАМН України О.В. Стефанов. -К. : Здоров'я, 2001. - 528 с.

5. Камышников В.С. Справочник по клиническо-биохимической лабораторной диагностике: в 2-х $m$. - Мн: Беларусь, 2002. T. 1. - 2002. - 495 с. T. 2. - 2002. - 463 c.

6. Койро O.O. Роль біологічно активних речовин яглиці звичайної (Aegopodium podagraria L.) у нефропротекторній, гепатопротекторній та гіпоурикемічній діï: Автореф. дис. ... к. фарм. наук. - Х., 2014. $-20 \mathrm{c}$.

7. Рябов С.И., Наточин Ю.В. Функциональная нефрология. - С.Пб.: Лань, 1997. - 304 с.

8. Товчига О.В. Дослідження сечогінної, нефропротекторної, гіпоурикемічної дії яглиці звичайної (Aegopodium podagraria L.) як основа для створення лікарських засобів: Автореф. дис.... к. фарм. наук. - Х., 2009. - 21 c.

9. Харкевич Д.А. Фармакология: Учебник. - М.: ГЭОТАР-Медиа, 2005. - С. 447.

10. Allon M. // J. Am. Soc. Nephrol. - 1992. - Vol. 2, №11. - P. 1593-1600.

11. Amador-Licona N., Guízar-Mendoza J., Vargas E. et al. // Arch. Med. Res. - 2000. - Vol. 31, №6. - P. 571-575.

12. Ferrannini E., Galvan A.Q., Santoro D., Natali A. //J. Hypertens. - 1992. - Vol. 10, №1. - P. S5-S10.

13. Lachin J.M., Viberti G., Zinman B. et al. // Clin. J. Am. Soc. Nephrol. - 2011. - Vol. 6, №5. - P. 1032-1040.

14. Orav A., Viitak A., Vaher M. // Proc. Chem. - 2010. - Vol. 2, №1. - P. 152-160.

15. Owolabi O.J., Omogbai E.K. // Trop. J. Pharm. Res. - 2012. - Vol. 11, №5. - P. 747-775.

16. Rehman S.U., Choi M.S., Choe K., Yoo H.H. // Arch. Pharm. Res. - 2015. - Vol. 38. - P. 1281-1298.

17. Tovchiga O. // Int. J. Biochem. Res. Rev. - 2014. - Vol. 4. - P. 80-98.

18. Tovchiga O.V. // BMC Compl. Altern. Med. - 2016. - Vol. 16. - Art. 235.

19. Tovchiga O.V.// Pharm. Sci. Tech. - 2016. - Vol. 1. - P. 80-98.

20. Tripathi Poonam, Gupta Prem Prakash, Lal Vijay Kumar // Am. J. Pharmacol. Toxicol. - 2013. - Vol. 8. - P. 102-106.

21. Yang Y., Zhang Z., Li S. et al. // Fitoterapia. - 2014. - Vol. 92. - P. 133-147.

\section{РЕНАЛЬНІ ЕФЕКТИ НАСТОЙКИ ЯГЛИЦІ ЗВИЧАЙНОÏ (AEGOPODIUM PODAGRARIA L.) TA METФOPMIHУ В ЩУРIB ІЗ ПОРУШЕННЯМИ МЕТАБОЛІЗМУ, СПРИЧИНЕНИМИ ДЕКСАМЕТАЗОНОМ \\ О.В.Товчига, С.Ю.Штриголь, А.В.Таран, Т.К.Юдкевич \\ Національний фармацевтичний університет}

Ключові слова: яглиця звичайна (Aеgороdium podagraria L.); дексаметазон; метформін; шури; комбіновані препарати; нирка

Настойка надземної частини яглищі звичайної (Aegopodium podagraria L.) характеризуєтся сприятливими метаболічними та органопротекторними ефектами і частково підвишує ефективність метформіну у тварин із порушеннями обміну речовин, спричиненими дексаметазоном. Мета даного дослідження - встановити ефективність настойки яглиці в поєднанні з метформіном на видільну функцію нирок та стан мінерального обміну у щурів, які отримують дексаметазон. Тварин рандомізували на 5 груп: інтактний контроль, дексаметазон (модельна патологія); дексаметазон + метформін, 50 мг/кг внутрішньошлунково (в/ш); дексаметазон + настойка яглищі, 1 мл/кг в/ш; дексаметазон + метформін, 50 мг/кг в/ш + настойка яглиці, 1 мл/кг в/ш. Дексаметазон вводили у дозі 5 мг/кг підшкірно впродовж 5 днів. На 5 день визначали стан видільної функції нирок в умовах 
водного діурезу. На тлі дексаметазону не спостерігали різких зсувів функціонального стану нирок. За поєднаного введення настойки яглиці та метформіну також не реєстрували несприятливих змін парціальних функцій нирок за незмінних показників транспорту натрію, як і електролітного складу крові. До переваг досліджуваної комбінації (порівняно з монотерапією метформіном) слід віднести зниження протеїнурії та ферментурії, а також нормалізацію вмісту калію у плазмі крові (підвищеного на тлі дексаметазону). Результати обгрунтовують доцільність поєднаного застосування настойки яглиці з метформіном після подальших досліджень цієї комбінації.

\section{РЕНАЛЬНЫЕ ЭФФЕКТЫ НАСТОЙКИ СНЫТИ ОБЫКНОВЕННОЙ (AEGOPODIUM PODAGRARIA L.) И METФOPMИНА У КРЫС С НАРУШЕНИЯМИ МЕТАБОЛИЗМА, ВЫЗВАННЫМИ ДЕКСАМЕТАЗОНОМ}

О.В.Товчига, С.Ю.Штрыголь, А.В.Таран, Т.К.Юдкевич

Национальный фармацевтический университет

Ключевые слова: сныть обыкновенная (Aеgopodium podagraria L.); дексаметазон; метформин; крысы; комбинированные препараты; почка

Настойка надземной части сныти обыкновенной (Aegopodium podagraria L.) характеризуется благоприятными метаболическими и органопротекторными эффектами и частично повышает эффективность метформина у животных с нарушениями обмена веществ, вызванными высокими дозами дексаметазона. Цель настоящего исследования - установить эффективность настойки сныти в сочетании с метформином на выделительную функцию почек и состояние минерального обмена у крыс, получающих дексаметазон. Животных рандомизировали на 5 групп: интактный контроль, дексаметазон (модельная патология); дексаметазон + метформин, 50 мг/кг внутрижелудочно (в/ж); дексаметазон + настойка сныти, 1 мл/кг в/ж; дексаметазон + метформин, 50 мг/кг в/ж + настойка сныти, 1 мл/кг в/ж. Дексаметазон вводили в дозе 5 мг/кг подкожно в течение 5 дней. На 5 день определяли состояние выделительной функции почек в условиях водного диуреза. На фоне дексаметазона резкие изменения функционального состояния почек не наблюдались. При сочетанном введении настойки сныти и метформина также не регистрировали неблагоприятных изменений парциальных функций почек при неизменных показателях транспорта натрия, как и электролитного состава крови. Преимущества исследуемой комбинации (по сравнению с монотерапией метформином): снижение протеинурии и ферментурии, а также нормализация содержания калия в плазме крови (повышенного на фоне дексаметазона). Результаты обосновывают целесообразность сочетанного применения настойки сныти с метформином после дальнейших исследований этой комбинации.

Address for correspondence:

Received in 23.11.2016

53, Pushkinskaya str., Kharkiv, 61002, Ukraine.

Tel. (57) 706-30-69. E-mail: olga_234@mail.ru.

National University of Pharmacy 